Haissig, B. E. \& Dickson, R. E. 1979. Starch measurements in plant tissue using enzymatic hydrolysis. Physiol. Plant. 47: $151-7$.

Hoyle, M. D. 1978. Agar studies in two Gracilaria species ( $G$. bursapastoris coronopfiolia) from Hawaii. I. Yield and gel strength in the gametophyte and tetrasporophyte generation. Seasonal aspects. Bot. Mar. 21:343-5.

Jackson, S. G. \& McCandless, E. L. 1978. Simple, rapid turbidimetric determination of inorganic sulfate and/or protein. Anal. Biochem. 90:802-8.

Jones, R. F., Speer, H. L. \& Kury, N. 1963. Studies on the growth of the red alga Porphyridium cruentum. Physiol. Plant. 16:63643.

Kim, C. S. \& Haumn, H. J. 1965. The red alga Gracilaria foliifera with special reference to cell wall polysaccharides. Bull. Mar. Sci. 15:1037-50.

Lapointe, B. E. 1981. The effects of light and nitrogen on growth, pigment content and biochemical composition of Gracilaria foliifera v. angostissima (Gigartinales, Rhodophyta). J. Phycol. $17: 90-5$

Lapointe, B. E., Tenore, K. R. \& Dawes, C. J. 1984a. Interactions between light and temperature on the physiological ecology of Gracilaria tikvahiae. Mar. Biol. (Berl.) 80:161-170.

Lapointe, B. E., Dawes, C. J. \& Tenore, K. R. 1984b. Interactions between light and temperature on the physiological ecology of Gracilaria tikvahiae. Mar. Biol. (Berl.) 80:171-8.

Lee, Van Thing. 1983. Effect of irradiance on the physiology and ultrastructure of the marine Cryptomonad cryptomonas strain Lis (Cryptophyceae). Phycologia 22:7-11.

Moon, R. E. \& Dawes, C. J. 1976. Pigment changes and pho- tosynthetic rates under selected wavelengths in the growing tips of Eucheuma. Br. Phycol. J. 11:165-74.

Oza, R. M. 1978. Studies on Indian Gracilaria. IV. Seasonal variation in agar and gel strength of Gracilaria croticata. Bot. Mar. 21:165-7.

Percival, E. 1968. Marine alga carbohydrates. Oceanogr. Mar. Biol. Annu. Rev. 6:137-61.

Provasoli, L. 1968. Media and prospects for the cultivation of marine algae. Cultures and collection of algae. In Watanabe, A. \& Hattori, A. [Eds.] Jap. Soc. Plant Physiol. USA-Japan Conference, pp. 63-75.

Ramus, J. 1972. The production of extracellular polysaccharide by the unicellular red alga Porphyridium aerugineun.J. Phycol. 8:97-111.

Sheath, R. G., Hellebust, J. A. \& Sawa, T. 1979. Floridean starch metabolism of Porphyridium purpureum (Rhodophyta). II. Changes during cell cycle. Phycologia 18:185-90.

Sumner, J. B. 1921. Dinitro-salicylic acid. A reagent for estimation of sugar in normal and diabetic urine. J. Biol. Chem. 47:5-9.

Whyte, J. N. C., Englar, J. R., Saunders, R. G. \& Lindsay, J. C. 1981. Seasonal variations in the biomass, quantity and quality of agar from the reproductive and vegetative stages of Gracilaria verrucosa. Bot. Mar. 24:493-501.

Yaphe, W. \& Arsenault, G. P. 1965. Improved resorcinol reagent for the determination of fructose and 3,6-anhydrogalactose in polysaccharides. Anal. Biochem. 13:143-8.

Young, K., Duckworth, M. \& Yaphe, W. 1971. The structure of agar. III. Pyruvic acid, a common feature of agars from different agarophytes. Carbohydr. Res. 16:446-8.

\title{
TWO NEW PLIOCENE SPECIES OF CYCLOSTEPHANOS (BACILLARIOPHYCEAE) WITH COMMENTS ON THE CLASSIFICATION OF THE FRESHWATER THALASSIOSIRACEAE ${ }^{1}$
}

\author{
Edward Theriot ${ }^{2}$ and John P. Kociolek \\ Great Lakes Research Division, The University of Michigan, Ann Arbor, Michigan 48109
}

\section{ABSTRACT}

Two new species of the diatom genus Cyclostephanos Round are described from Pliocene fossil deposits in western North America. Cyclostephanos undatus is distinguished from other Cyclostephanos species by its tangentially undulate valve face; Cyclostephanos fenestratus is distinguished by its extremely shallow alveoli. This paper records previously unreported morphological detail of $\mathbf{C y}$ clostephanos and speculates that structure of the punctum, labiate process and strutted process may enhance diagnosis of the freshwater genera of the Thalassiosiraceae Lebour emend. Hasle. Cyclostephanos undatus is similar to several Cyclotella species, but its external costae are raised and its alveolar morphology is similar to that of Cyclostephanos dubius (Fricke) Round. Cyclostephanos fenestratus is similar in external view to Stephanodiscus Ehrenb. However, the two species described here have flat cribra covering the mantle puncta and the

\footnotetext{
1 Accepted: 30 November 1985.
}

2 Address for reprint requests. labiate processes appear to lack external tubes, whereas Stephanodiscus species have domed mantle cribra and external tubes.

Key index words: Bacillariophyceae; Cyclostephanos; Cyclotella; diatom; fossil; Pliocene; Stephanodiscus; Tertiary; Thalassiosiraceae

The diatom genus Cyclostephanos Round (1982) originally included two species, C. dubius (Fricke) Round and C. novaezeelandiae (Cleve) Round. A third species was added later, $C$. damasi (Hustedt) Stoermer et Håkansson (1983). The latter two species were each originally described as species of Stephanodiscus Ehrenb. (Cleve 1881, Hustedt 1949), while C. dubius was initially placed in Cyclotella (Fricke 1900, in Schmidt 1874-1959) and later transferred to Stephanodiscus by Hustedt (1930). These changes reflect the taxonomic difficulties associated with the freshwater genera of the family Thalassiosiraceae Lebour emend. Hasle.

This paper describes two new fossil diatom species, 


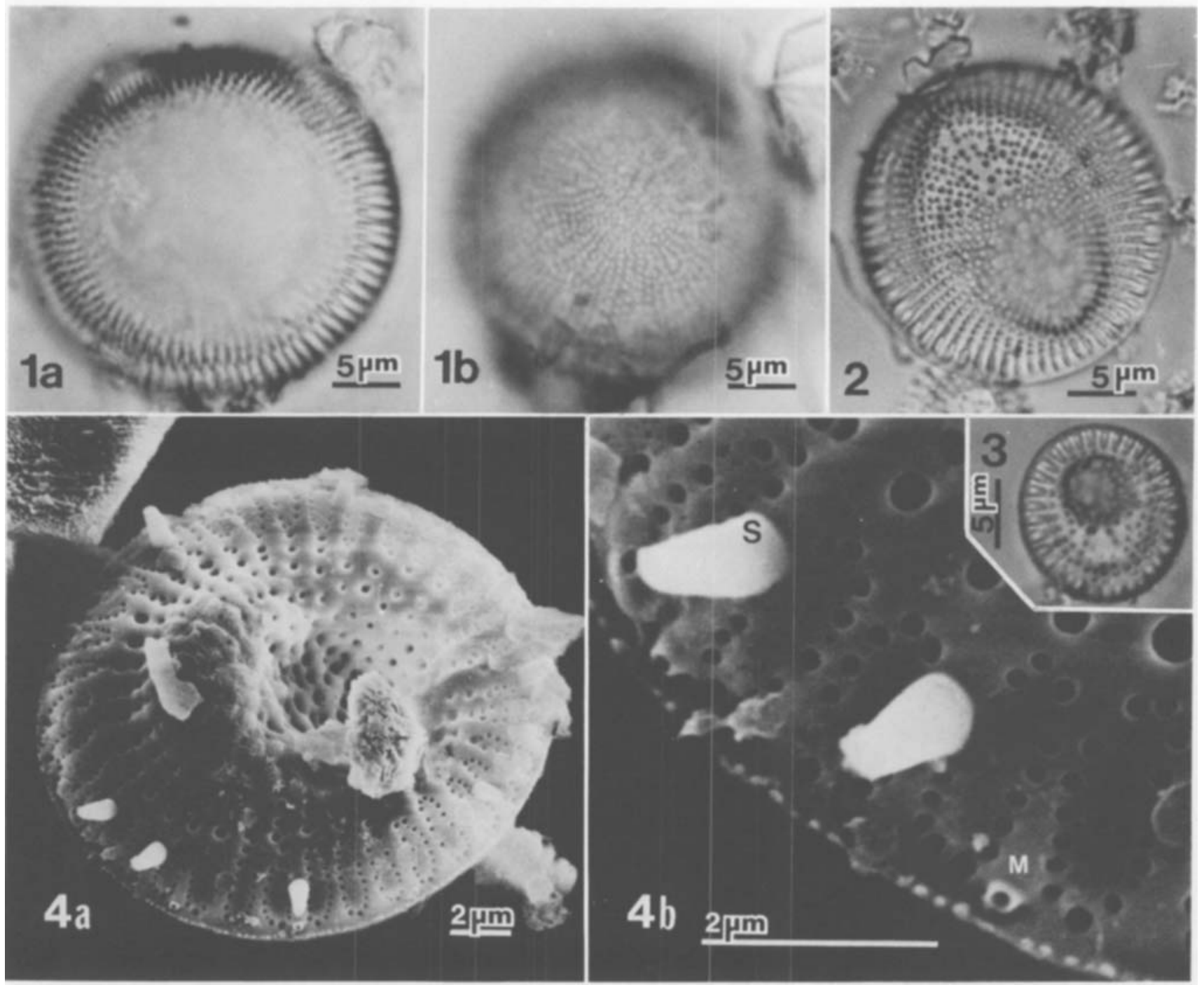

Figs. 1-4. Cyclostephanos undaius. FIG. 1a, b. Initial cell in bright field LM: different planes of focus. Figs. 2, 3. Bright field LM of representative large and small valves. FIG. 4a. External SEM of entire valve. Fig. 4b. Detail of mantle region of specimen of Fig. 4a, identifying a spine (S) and mantle strutted process $(\mathrm{M})$.

which are tentatively placed in Cyclostephanos. It also reviews the distinctions between Stephanodiscus, Cyclostephanos and Cyclotella (Kützing) Brébisson, and includes observations on new and/or poorly known characters for these genera.

\section{MATERIALS AND METHODS}

We studied material from two locations; Christmas Valley, Lake County, Oregon, and Shasta County, California. The Christmas Valley diatomite is Miocene-Pliocene in age (4-7 million years before present, Ma; detailed in Colbath and Steele 1982) and a sample (OD Section $0.0 \mathrm{M}$ ) was obtained through the courtesy of Dr. G. Kent Colbath (Smithsonian Institution). The Shasta County diatomite was obtained from the Academy of Natural Sciences (ANSP bottle 5293-3), collected by Dr. Samuel L. VanLandingham. VanLandingham (unpubl.) believes that the formation from which the material was collected can be correlated with the Yonna Formation and so may be of Blancan age (early Pliocene, $4.5 \mathrm{Ma}$ ). Uncleaned samples were suspended in distilled water and allowed to dry on cover slips. For light mi- croscopy (LM), specimens were embedded in Hyrax and observed using bright field optics. Measurements of diameter, puncta per $10 \mu \mathrm{m}$ and total number of fascicles were made as by Theriot and Stoermer (1984). Total fascicle count was transformed to fascicles per $10 \mu \mathrm{m}$ of circumference. For scanning electron microscopy (SEM), specimens were coated with gold-palladium, and observed with an ISI DS-1 30 fitted with either $\mathrm{a} \mathrm{LaB}_{6}$ or tungsten gun operated at $10-15 \mathrm{kV}$.

\section{SPECIES DESCRIPTIONS}

\section{Cyclostephanos undatus sp. nov.}

(Figs. 1-6)

Valves 3-28 $\mu \mathrm{m}$ in diameter, with 8-16 puncta and 7-11 fascicles per $10 \mu \mathrm{m}$. Valve face tangentially undulate. Alveoli partially covered by a lamina extending from the valve face. Puncta of the valve face with domed cribra, of the alveoli and mantle with flat cribra. Radiating striae, uniseriate on the valve face and multiseriate at the junction of the valve 


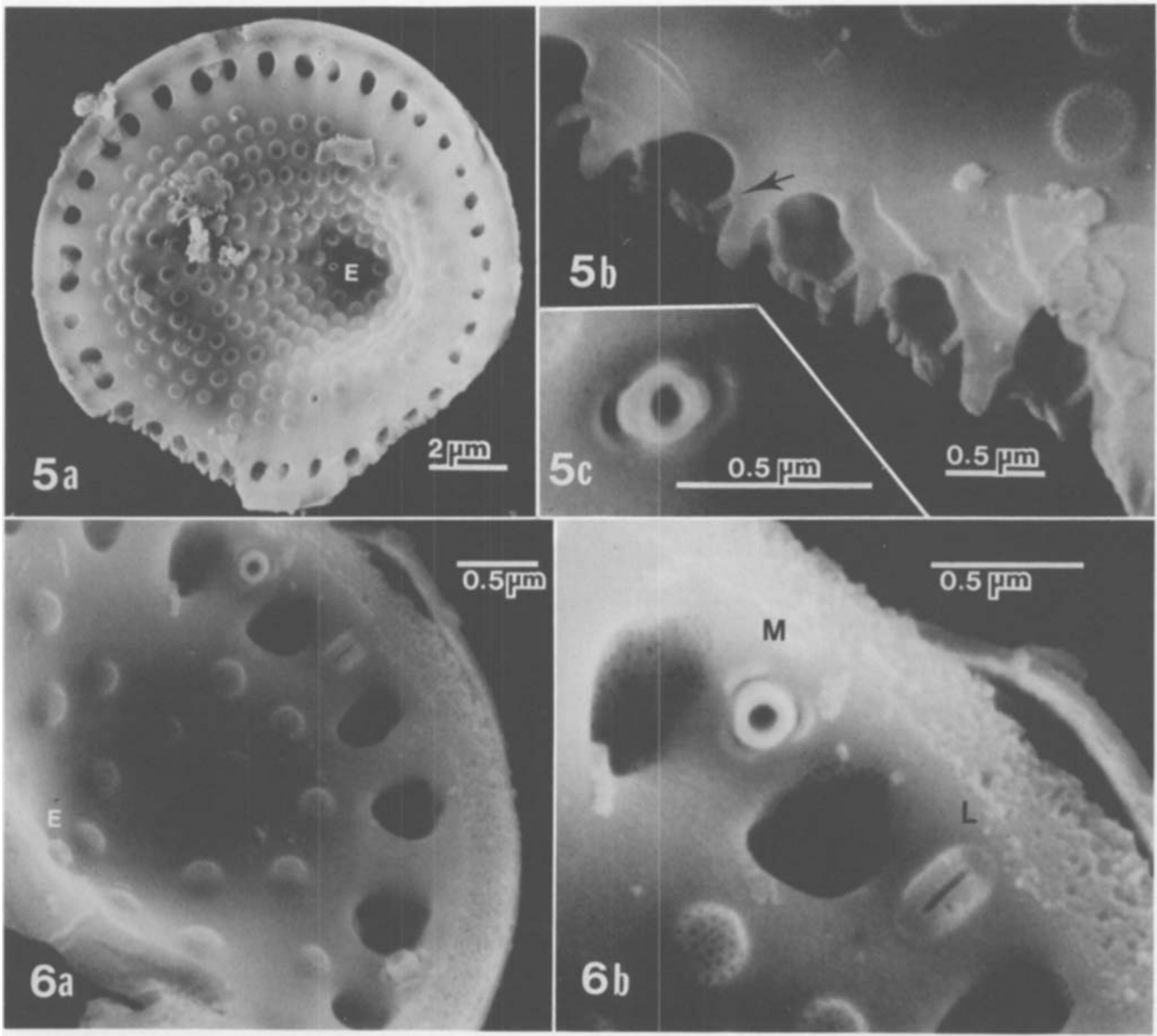

Figs. 5, 6. Cyclostephanos undatus, valve interior, SEM. Fig. 5a. Entire valve. Fig. 5b. Detail of broken mantle area in lower left of Fig. 5a, illustrating portions of broken cribra (arrow). Fig. 5c. Eccentric strutted process in Fig. 5a (E). Fig. 6. a, b. Orientation and detail of a second specimen, illustrating the labiate process $(L)$, and the eccentric $(E)$ and mantle $(M)$ strutted processes.

face and mantle. Striae separated by costae which continue over the valve mantle to the margin. One eccentrically located strutted process on the valve face; each of the two satellite pores partly occluded by a ridge-shaped operculum arising from the tube surrounding the central pore. One mantle strutted process for every 3-5 costae. One labiate process just inside the ring of mantle processes, always located on the mantle area on the same side of the valve as the eccentric inflation. Labiate process lacking an external tube.

Holotype. Slide A-G.C. 64152a at the diatom herbarium of the Academy of Natural Sciences of Philadelphia (ANSP).

Isotypes. LM preparations and/or unprepared ma- terial: ANSP A-G.C. $64152 \mathrm{~b}$, the Great Lakes Research Division diatom herbarium (GLRD), Theriot's personal collection ECT-651 (GLRD), Kociolek's personal collection (GLRD), the British Museum (Natural History) B.M. 81049, and Bremerhaven $\mathrm{Zu} \mathrm{3/44.}$

Type locality. OD Section $0.0 \mathrm{~m}$, diatomite at Fort Rock basin, Christmas Valley, Lake County, Oregon, NW 1/4 NW 1/4 sec. 23, T27S, R16E. Geology described in Colbath and Steele (1982).

Known distribution. In addition to the type locality, diatomaceous earth $5.6 \mathrm{~km}$ west of town of Alturas, Modoc County, California, NW of "Barnes Grade" and California highway 299 junction, $450 \mathrm{~m} \mathrm{~W}$ and $50 \mathrm{~m} \mathrm{~S}$ of NE corner of sec. 7, T42N, R12E, Big 


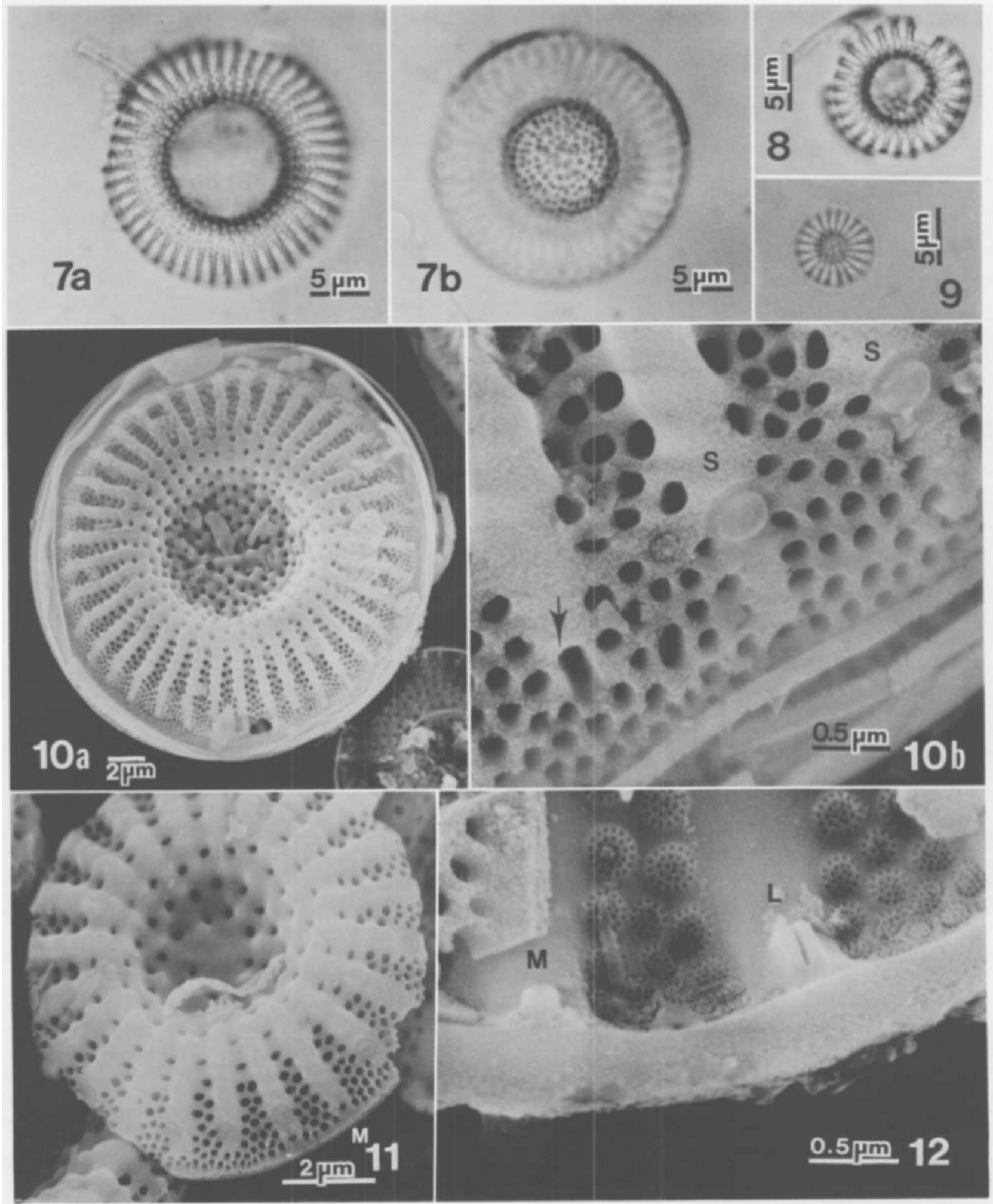

Figs. 7-12. Cyclostephanos fenestratus. Figs. 7-9, LM; 10-12, SEM. Fig. 7a, b. Different planes of focus of large specimen. FiG. 10 a, b. Entire valve and detail of mantle of same specimen. The probable external aperture of a labiate process (arrow); note also costae bearing spines (S). FIG. 11. Small specimen in external view illustrating mantle strutted process location (M). FIG. 12. Internal SEM detail of mantle region with strutted $(M)$ and labiate $(\mathrm{L})$ process. 
Sage $15^{\prime}$ quadrangle. According to Bradbury (unpubl.) the diatomaceous sediments at this locality contain the "Upper Alturas Fauna" of early Blancan (Pliocene) age with an age of $4.8 \mathrm{Ma}$ (Repenning 1978), corresponding well to the age of the type material.

Associated diatom taxa. In the type material, Stephanodiscus spp., Melosira spp., Cymbella spp. and Fragilaria spp. are very low in proportionate abundance compared to the dominant $C$. undatus. Colbath and Steele (1982) give a complete geologic distribution of associated genera, mentioning that Cyclotella spp. (probably $=$ Cyclostephanos undatus) is the dominant taxon.

Comments on morphology. The maximum diameter reported here is probably fully representative of the species. Domed shaped valves with alveoli (Fig. 1) are probably initial valves, and are only slightly larger than the largest vegetative valves observed (Fig. 2).

Valves of Cyclostephanos undatus are not strictly rotationally or radially symmetric, less so even than most centric diatoms which commonly have minor asymmetric features. The tangentially undulate valve (Figs. 2-4) has one eccentric strutted process near the origin of the striae (Figs. 5, 6), either on the inflation or deflation.

The only large external processes observed were spines, which were generally well preserved (Fig. 4). Some were missing but left a pad as a remnant as do living and cultured material (Round 1981, Theriot and Stoermer 1981, unpubl.) All specimens observed in the SEM had spines or spine bases near the junction of the face and mantle. Some had a spine on every costa, others had more irregular arrangements.

The labiate process does not appear to have an external spine-like extension. Its internal position relative to marginal strutted processes and the eccentric inflation yields landmarks to locate the labiate externally. That is, it should be found at the margin on a costa on the same side as the inflation. Other than a costa which terminates in a non-descript punctum (observed on at least two valves), there is no evidence of external expression of a labiate process.

\section{Cyclostephanos fenestratus sp. nov.} (Figs. 7-16)

Valves $7.5-29 \mu \mathrm{m}$ in diameter, with $20-25$ puncta and 5-9 fascicles per $10 \mu \mathrm{m}$. Valve face with either a concave or convex central area. Alveoli on the valve face and mantle, shallow without laminae. Puncta of the valve face with domed cribra, of the alveoli and mantle with flat cribra. Striae radiate, in fascicles separated on the valve face by prominent costae; uniseriate centrally, becoming multiseriate towards the junction of the face and mantle. Strutted processes only on the mantle, one at the end of every $1-4$ costae. One labiate process inside the ring of mantle processes, without an external tube. Costae without strutted or labiate processes end at the junction of the valve face and mantle; those with such processes end at the process on larger specimens, but continue to the valve margin on smaller specimens.

Holotype. Slide A-G.C. 64151 a at the diatom herbarium of ANSP.

Isotypes. LM preparations and unprepared material; ANSP bottle 5293(3) and slide A-G.C. 64151b, Theriot's personal collection ECT-708 (GLRD), Kociolek's personal collection (GLRD), the British Museum (Natural History) B.M. 81050, and Bremerhaven $\mathrm{Zu} \mathrm{3/43.}$

Known distribution. Only from type locality, i.e. lower $3 \mathrm{~m}$ of roadcut on $\mathrm{S}$ side of California state highway 89 (CA 89), $2.1 \mathrm{~km}$ W of Lake Britton Bridge, $10.2 \mathrm{~km} \mathrm{~N}$ of junction of CA 89 and U.S. highway $299, \mathrm{E} 1 / 2$ sec. 29 , T37N, R3E, $41^{\circ} 00^{\prime} 56^{\prime \prime}$ $\mathrm{N} \times 121^{\circ} 38^{\prime} 45^{\prime \prime} \mathrm{W}$.

Associated diatom taxa. Stephanodiscus carconensis Grunow, Melosira spp. and C. fenestratus dominate the assemblage on the holotype and isotype slides, occurring in roughly equal proportions. The rarely reported rhomboid-shaped S. rhombus Mahood is present in low proportionate abundance.

Comments on morphology. Small depressions relative to the costae correspond to the region of the flattened cribra (Figs. 12, 16). We use the term alveolus to describe each of these marginal chambers, following the definition of Anonymous (1975). In the LM, alveoli appear as clear areas of the valve in critical focus on suitable specimens and this suggested to us the specific epithet selected.

There are three types of valve processes. Strutted processes occur only on the mantle. Spines were generally eroded or broken, leaving behind a small pad (Figs. 10-11). The single labiate process is a radially oriented raised slit located inside the ring of mantle strutted processes (Figs. 12-15). A costa without a spine, tube or remnant of either was observed to end in a large punctum in some specimens (e.g. Fig. 10b). Its location relative to the junction of the face and mantle and to the position of strutted processes suggests that this punctum is the external expression of the labiate process.

\section{DISCUSSION}

The classification of the freshwater Thalassiosiraceae is in a state of flux. Stephanodiscus as represented by the lectotype of the genus, $S$. niagarae Ehrenb., lacks alveoli but has prominently raised costae externally (Håkansson and Locker 1981, Round 1981, Theriot and Stoermer 1981). Nomenclatural problems surrounding the type species of Cyclotella notwithstanding (Håkansson and Ross 1984), Cyclotella has alveoli (Round 1970, 1982), but nearly all species in Cyclotella lack prominently raised 

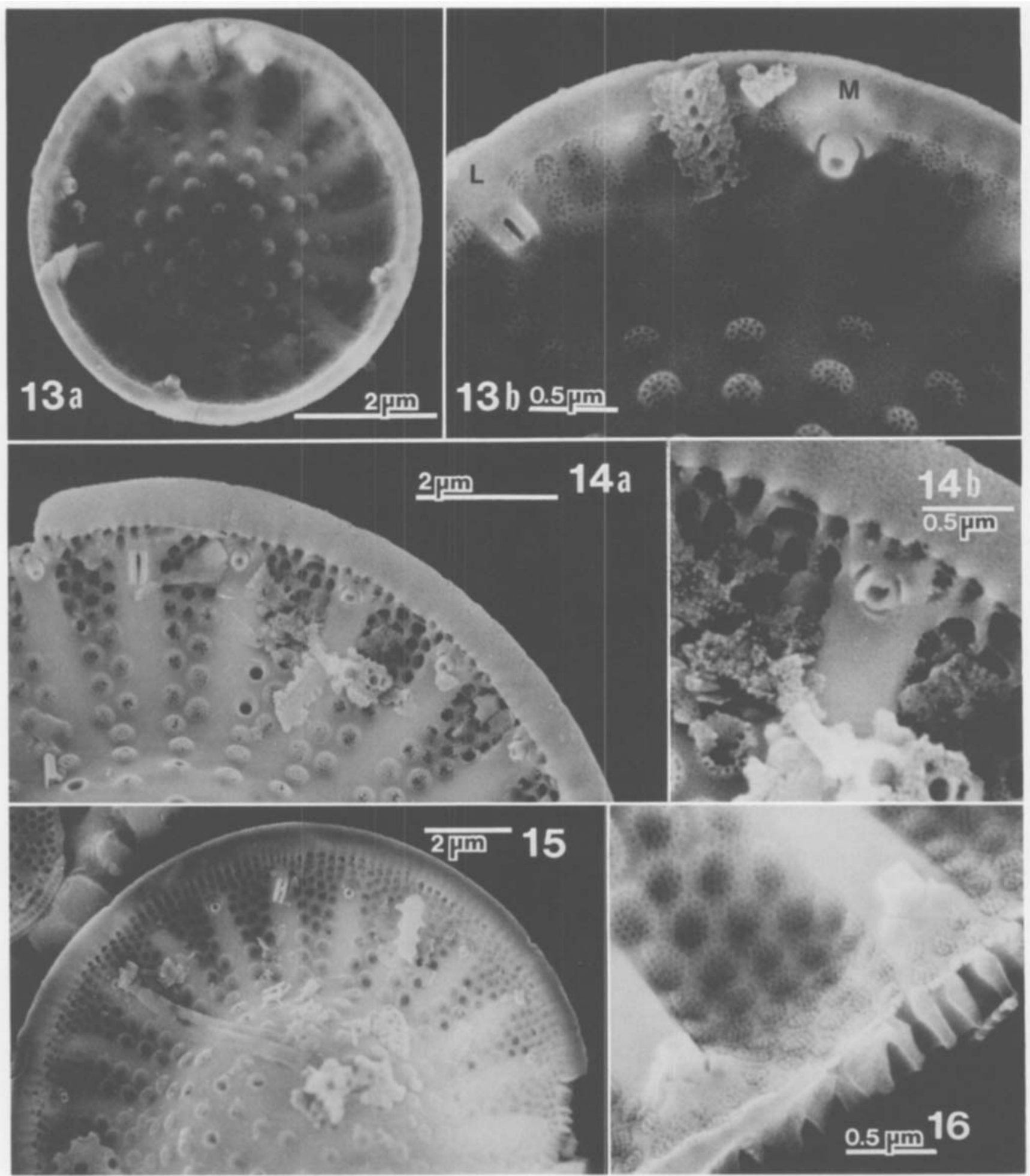

Figs. 13-16. Cyclostephanos fenestratus, valve interior, SEM. Fig. 13a, b. Entire valve and detail of small specimen, illustrating arrangement of mantle strutted (M) and labiate process (L). Fic. 14a, b. Detail of mantle region and mantle strutted process, respectively, of a medium sized specimen with a labiate or mantle process on every costa. Fig. 15. Specimen with one strutted process on every other costa. Fig. 16. Detail of mantle region illustrating flat cribra and slight depression marking the alveolus. Each punctum appears to be slightly constricted near its cribrum. 
costae externally (Lowe 1975, Serieyssol 1981, 1984, Theriot et al. 1985). Cyclostephanos is diagnosed by having characters of both genera: prominently raised Stephanodiscus-like costae and Cyclotella-like alveoli (Round 1982, Stoermer and Håkansson 1983).

All three genera need revision. No species underscore this need more than those described here, and we regard their classification as tentative. Each has the combination of characters considered diagnostic of Cyclostephanos: alveoli and externally raised costae (Round 1982). We propose that Stephanodiscus possesses unique characters definitely excluding the new species from that genus. Differences between Cyclotella and Cyclostephanos remain less certain.

Not only does Cyclostephanos undatus have the characters of Cyclostephanos, it is very similar in overall morphology to Cyclostephanos dubius. In both species, costae bearing strutted processes are smaller than those without processes, and uniseriate rows of domed cribra extend from the valve center to the edge of the alveoli which extend from the margin to slightly beyond the junction of the mantle and face (Håkansson 1976, Descourtieux-Coqueugniot 1981, Round 1982). Some specimens of C. dubius also appear to have alveoli with small laminae extending from the valve face (Descourtieux-Coqueugniot 1981). Cyclostephanos undatus is best distinguished from $C$. dubius by the tangential undulation of the valve of the former and the concentric undulation of the latter.

Round (1982) placed Cyclostephanos intermediate to the other two freshwater Thalassiosiraceae genera along a morphological continuum. Cyclostephanos undatus lies towards the Cyclotella side of Round's continuum, resembling Cyclotella omarensis (Kuptzova) Loseva and Makarova and Cyclotella ovata Tynni. All three are tangentially undulate with puncta in uniseriate rows extending to near the junction of the valve face and margin (Loseva and Makarova 1977, Loseva 1981, Tynni 1982). There are no published SEM illustrations of the latter species but it is easily distinguished from Cyclostephanos undatus by its strongly ovate valve outline. In Cyclotella omarensis, however, the labiate process is on the valve face, costae bearing strutted processes are much larger than those without processes and there is no lamina covering the valve face portion of the alveolus (Loseva 1981). Even in the LM, it can be seen that the alveoli of Cyclostephanos undatus are not subdivided by small costae, whereas those of Cyclotella omarensis are (e.g. Gasse 1980, Loseva 1981). Although useful for species identification, these characters vary within each genus and do not completely distinguish the genera under the present classification.

The morphology of Cyclostephanos fenestratus lies towards the Stephanodiscus end of Round's continuum in that the alveolus is minimal in size in $C$. fenestratus and completely absent in Stephanodiscus. However, we propose that labiate process and cribrum morphology separate Cyclostephanos and Stephanodiscus. Stephanodiscus species have external extensions of the labiate process. There is no apparent external extension of the labiate process of either Cyclostephanos species described here. The presence or absence of an extension is unknown for other Cyclostephanos taxa; all Cyclotella species appear to lack an external extension of the labiate process. All Stephanodiscus species with which we are familiar have domed cribra on the mantle, including the type species (Håkansson and Locker 1981, Round 1981, Theriot and Stoermer 1981). Cyclostephanos species have domed cribra restricted to the valve face. The mantle cribra are flat in Cyclostephanos undatus and Cyclostephanos fenestratus, the only species of the genus having the character so resolved. Domed cribra are also restricted to the valve face for those Cyclotella species with such features; it is unclear if the mantle puncta have flat cribra or no cribra (Lowe 1975, Gasse 1980, Theriot et al. 1985).

In conclusion, Round's concept of a continuum in the freshwater Thalassiosiraceae is not supported by the available data. A large obstacle to even a firstorder approximation of relationships is that much primary descriptive work is still lacking. If our observations on these new species are also valid for other Cyclostephanos and Cyclotella, then Stephanodiscus is a well defined group with at least two unique characters: domed mantle cribra and external tube of the labiate process. However, distinctions between Cyclostephanos and Cyclotella are still based on the degree of interfascicle costae thickness. We believe that the latter two genera should not be joined at this time. Cyclotella and Cyclostephanos each appear to be paraphyletic groups (e.g. not all descendants of the most recent common Cyclotella ancestor can be included in Cyclotella), and combined also form a larger paraphyletic group (Theriot, unpubl.). There is therefore no compelling reason to join them. $C y$ clotella and Cyclostephanos are each morphologically diverse groups. No less than eight morphologically homogenous subgeneric groups have been informally described within Cyclotella; some of which can be uniquely diagnosed by at least one character (Lowe 1975, Serieyssol 1981, 1984, Theriot et al. 1985). Thus splitting of taxa within Cyclotella and Cyclostephanos into diagnosable groups is likely to result in a more natural classification of the freshwater genera of the Thalassiosiraceae.

Herbarium research was supported by an Academy of Natural Sciences of Philadelphia (ANSP) McHenry Fellowship to ET. S. L. VanLandingham and J. P. Bradbury provided valuable data, samples and discussion. C. W. Reimer and R. K. Mahoney made visits to the ANSP diatom herbarium extremely profitable, and B. Donohoe assisted with electron microscopy. Contribution no. 444 of the University of Michigan Great Lakes Research Division 
was supported by National Science Foundation grant no. NSFBSR-8412306 to E. F. Stoermer.

Anonymous. 1975. Proposals for a standardization of diatom terminology and diagnoses. Nova Hedwigia, Beih. 53:323-54.

Cleve, P. T. 1881. On some new and little known diatoms. Kongl. Szienska Vetenskaps.-Akad. Handl. 18:1-28.

Colbath, G. K. \& Steele, M. J. 1982. The geology of economically significant Lower Pliocene diatomites in the Fort Rock basin near Christmas Valley, Lake County, Oregon. Oregon Geol. 44:111-18.

Descourtieux-Coqueugniot, C. 1981. Stephanodiscus dubius (Fricke) Hustedt: étude en microscopie optique et en microscopie électronique. Bull. Mensuel Soc. Linn. Lyon. 50:244-49.

Gasse, F. 1980. Les diatomées lacustres plio-pléistocenes du Gadeb (Êthiopie). Systématique, paléoécologie, biostratigraphie. Rev. Algol., Mém. hors-sér. 3:1--249.

Håkansson, H. 1976. Die Struktur und Taxonomie einiger Stephanodiscus-Arten aus eutrophen Seen Südschwedens. Bot. Notiser 129:25-34.

Håkansson, H. \& Locker, S. 1981. Stephanodiscus Ehrenberg 1846 a revision of the species described by Ehrenberg. Nozia Hedwigia 35:117-50.

Håkansson, H. \& Ross, R. 1984. Proposals to designate conserved types for Cymbella $\mathrm{C}$. Agardh and Cyclotella (Kützing) Brébisson, and to conserve Rhopalodia $\mathrm{O}$. Müller against $P y x i-$ dicula Ehrenberg (all Bacillariophyceae). Taxon 33:525-31.

Hustedt, F. 1930. Die Kieselalgen Deutschlands, Österreichs und der Schweiz mit Berücksichtigung der übrigen Länder Europas sowie der angrenzenden Meeresgebiete. In Rabenhorst, L. (Ed.) Kryptogamen-Flora von Deutschland, Österreich und der Schweiz 7(1). Akademische Verlagsgesellschaft, Leipzig, $920 \mathrm{pp}$

_ 1949. Süsswasser-Diatomeen aus dem Albert-Nationalpark in Belgisch-Kongo. Inst. des Parcs Nationaux du Congo Belge. Mission H. Damas 1935-1936. Fascicule 8. Hayez, Brussels, $199 \mathrm{pp}$.

Loseva, E. I. 1981. The valve structure of some fossil Cyclotella species. In Ross, R. (Ed.) Proceedings of the Sixth Symposium on Recent and Fossil Diatoms. O. Koeltz, Koenigstein, pp. 15-26.

Loseva, E. I. \& Makarova, I. V. 1977. De specie Cyclotella Kütz. nova notula. Now. Syst. Nizshikh Rast. 14:29-32.
Lowe, R. L. 1975. Comparative ultrastructure of the valve of some Cyclotella species (Bacillariophyceae). J. Phycol. 11:41524.

Repenning, C. A. 1978. Faunal exchanges between Siberia and North America. Abstracts of Fifth Biennial Meeting, American Quaternary Association, 2-4 September, 1978, Univ. of Alberta, Edmonton, Alberta, pp. 40-55.

Round, F. E. 1970. The delineation of the genera Cyclotella and Stephanodiscus by light microscopy, transmission and reflecting electron microscopoy. Nova Hedwigia 31:583-604.

- 1981. The diatom genus Stephanodiscus: an electron microscopic view of the classical species. Arch. Protistenk. 124: 455-70.

- 1982. Cyclostephanos-a new genus within the Sceletonemaceae. Arch. Protistenk. 124:323-9.

Schmidt, A. 1874-1959. Atlas der Diatomaceenkunde. Tafel 222. O.R. Riesland, Leipzig.

Serieyssol, K. K. 1981. Cyclotella species of late Miocene age of St. Bauzile, France. In Ross, R. (Ed.) Proceedings of the Sixth Symposium on Recent and Fossil Diatoms. O. Koeltz, Koenigstein, pp. 27-42.

1984. Cyclotella iris Brun \& Heribaud. In Mann, D, G. (Ed.) Proceedings of the Seventh International Diatom Symposium. O. Koeltz, Koenigstein, pp. 197-212.

Stoermer, E. F. \& Håkansson, H. 1983. An investigation of the morphological structure and taxonomic relationships of Stephanodiscus damasii. Bacillaria 6:245-56.

Theriot, E. \& Stoermer, E. F. 1981. Some aspects of morphological variation in Stephanodiscus niagarae (Bacillariophyceae). J. Phycol. 17:64-72.

- 1984. Principal component analysis of variation in Stephanodiscus rotula and S. niagarae (Bacillariophyceae). Syst. Bot. 9:53-9.

Theriot, E., Carney, H. J. \& Richerson, P. 1985. Morphology, ecology and systematics of Cyclotella andina sp. nov. (Bacillariophyceae) from Lake Titicaca, Peru-Bolivia. Phycologia $24: 381-7$

Tynni, R. 1982. The reflection of geological evolution in Tertiary and interglacial diatoms and silicoflagellates in Finnish Lapland. Geological Survey of Finland Bulletin $320.40 \mathrm{pp} .+$ 21 Plates. 